\title{
The Dental Identification of the Egyptian Queen Hatshepsut
}

\section{Riaud X}

DDS, PhD in Epistemology, History of Sciences and Techniques, Laureate and Associate member of the National Academy of Dental Surgery, Free Member of the National Academy of Surgery.145, Route de Vannes, 44800 Saint Herblain, France

*Corresponding author: Riaud X, DDS, PhD in Epistemology, History of Sciences and Techniques, Laureate and Associate member of the National Academy of Dental Surgery, Free Member of the National Academy of Surgery.145, Route de Vannes, 44800 Saint Herblain, France, E-mail: xavier.riaud@wanadoo.fr

Citation: Riaud X (2016) The Dental Identification of the Egyptian Queen Hatshepsut. J Dent Oral Care Med 2(1): 108. doi: 10.15744/2454-3276.2.108

Received Date: December 19, 2015 Accepted Date: February 09, 2016 Published Date: February 10, 2016

\begin{abstract}
Recently, an Egyptian archaeologist, Dr Zahi Hawass, found few mummies. He was convinced that one of them was Hatshepsut, the famous Egyptian queen. After many researches, this one was clearly identified thanks to a single tooth.
\end{abstract}

Keywords: Archaeology; Forensic Dentistry; History

\section{Who was she?}

When Thutmose II died in 1479 B.C. after a short reign [1], he left behind only one son, a young Thutmose III, to succeed him. However, the latter was not born as the son of the Great Royal Wife, Hatshepsut (she was the fifth Queen-pharaoh of the eighteenth dynasty of Ancient Egypt, his half-sister, but as the son of a lesser wife of Thutmose II. The Queen decided to proclaim herself as the full-fledged "King" of Egypt. Therefore, Hatshepsut became the co-regent of Egypt at this time, assumed the responsibilities of state as the Great Royal Wife, and the wife of the God Amun. Her decisions were made in the name of the reigning King, Thutmose III. In the seventh year of the young monarch's reign, the Queen wore the royal crowns and adopted all royal symbols; the full royal titulary consisted of five titles and five names, scepters, the false beard, the short loincloth and the bull's tail, which were symbols of power. Soon she proclaimed to be the daughter of Amun-Ra, the King of the Egyptian Gods, who had chosen her to succeed him [1]. Hatshepsut claimed that not only she was her father's intended heir but also that he made her the heir apparent of Egypt. Hatshepsut sat on the throne next to Thutmose III but did not plan to replace him. Indeed, even if two kings existed, only one royal function remained. The Queen trained the young King to take his responsibility in the future. The latter became a noteworthy war chief. Hatshepsut was one of the most prolific builders in ancient Egypt. Her last attestations date back to the year 1499. When she died, Thutmose III organised her funeral and remained the King. However, during the year 1501-1502, the King ordered the removal of all the images representing her from the temples. Her name also disappeared. The priest, Manetho ( $3^{\text {rd }}$ century B.C.), reported that she reigned for twenty two years. She distinguished herself with her subtle intelligence and an iron will.

\section{Looking for Hatshepsut...}

In 1903 her tomb, which is located in the Valley of the Kings near Thebes, was explored by Howard Carter (1874-1939), a British Egyptologist who also discovered the tomb of Tutankhamun. Her royal tomb was called KV20. It was found empty [2], and her body could not be found. Zahi Hawass, the Secretary General of Egypt's Supreme Council of Antiquities, led a scientific police investigation throughout the country to find the mummy of the Queen [3,4]. He searched for exhumed mummies but the task was not easy - hidden and scattered by the great priests so that looters cannot get their hands on them, the royal spoils were numerous in Egypt. This is why Hawass founded the Egyptian Mummy Project, which studies mummies by CT scanning (3D imaging) the body [5].

\section{The investigation begins}

Accompanied by a team of researchers, he began his investigation with a visit to a small tomb located in front of KV20, called KV60. This burial place, discovered by Carter in 1903, contained two mummies of the $17^{\text {th }}$ dynasty: a small one, identified as that of the royal wet-nurse, Sitre-In, and that of an obese one, which was found on the ground $[3,4]$. 
After having cleared the entrance, Zahi found a rudimentary wooden box that contained the mortal remains of the obese woman. Noticing her stately demeanor, her left arm folded on her chest like royal mummies, he was convinced of the monarchical ancestry of her body. He immediately took her remains to the Museum of Cairo for more detailed study.

As for the mummy of the wet nurse, it was taken to the museum of the Egyptian capital. Hawass considered that she could be an interesting candidate [2].

The team remembered two royal mummies found in another tomb near the temple of Deir el-Bahari (DB320).

The burial site, which was excavated during the $19^{\text {th }}$ century by the department of the Egyptian Antiquities, hid more than a dozen mummies of pharaohs from several dynasties, including Ahmose I, Thutmose I and III and Ramesses II [3,4].

\section{Comparative study}

Along with the bodies, named Unknown woman A and Unknown woman B, a sealed vase was found bearing the name Hatshepsut [3].

After having being stored in the Museum of Cairo after their exhumations, the two bodies were forgotten and abandoned in dark and dusty corridors. Numerous days passed before the two women were finally found again.

A comparison of the four mummies (the two from the KV60 tomb and the two from the DB320) was finally possible.

A 3D reconstitution of each mummy was carried out by Doctor Ashraf Selim, a radiologist, and Doctor Hany Abdel Rahman Amer. Each scanned portrayal was compared to the reconstituted portrayal according to the data collected on Thutmose I, II and III. They soon came to a conclusion - the bodies of the site DB320 were ruled out [4].

To confirm the blood connection between the two other mummies and the descent of Thutmose, the experts carried out DNA examinations. Samples were taken from the hip and femur of the two mummies, and were compared to those of Hatshepsut's grand-mother, Queen Ahmes-Nefertari. It took months before the results returned [2]. Due to the aforementioned problems, the on-going DNA analysis and the need for a published report on the subject, preliminary DNA data cannot currently be used to identify KV60-A as Pharaoh Hatshepsut.

The investigation did not go any further. Which of the two mummies could be Hatshepsut? The obese or the wet nurse?

\section{A Queen who did not have all her teeth...}

This was when Zahi Hawass remembered the funeral vase with the Queen's seal.

The urn was scanned. Among the embalmed organs, nothing extraordinary was taken down except for the fragment of a molar [4]. However, one of the two mummies had poor teeth: broken teeth, roots, teeth decays [2].

Professor Galal el-Beheri, a professor of orthodontics at the Dental University of Cairo, was also approached to examine the body's teeth. The dentist carried out a study of the facial scanning, compared the teeth and the fragment, and finally came to the conclusion that the piece found in the vase of the tomb DB320 belonged to a molar from the jaw of the obese woman of the tomb KV60. The report mentioned a fragment of a tooth of $1,6 \mathrm{~cm}$ in width for a space of $1,7 \mathrm{~cm}$ (Figure 1) [4].

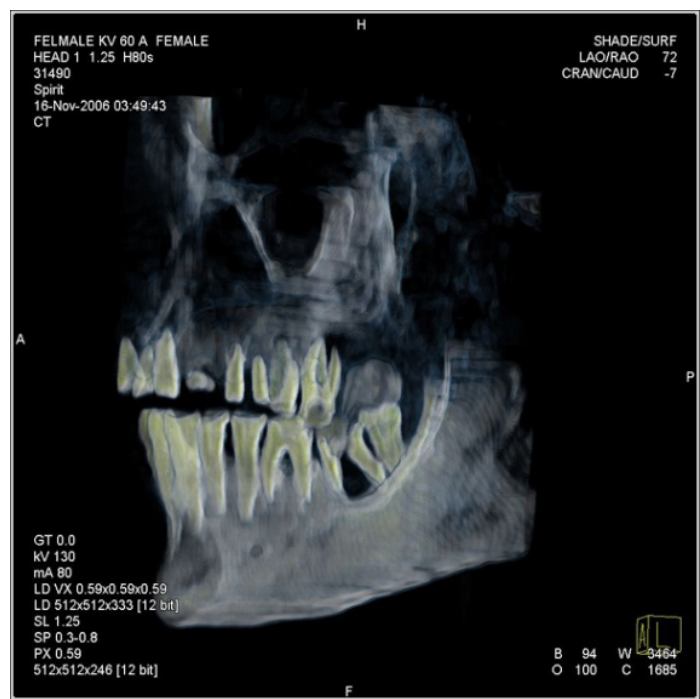

Figure 1: Scan of the obese woman of the tomb KV60, identified as being Queen Hatshepsut, which revealed the absence of a molar, but the persistence of the root, $\odot$ The Supreme Council of Antiquities [6] 
Hatshepsut was finally identified. She supposedly died around the age of 50 years old (Figure 2).

This discovery was officially announced on June 27, 2007.

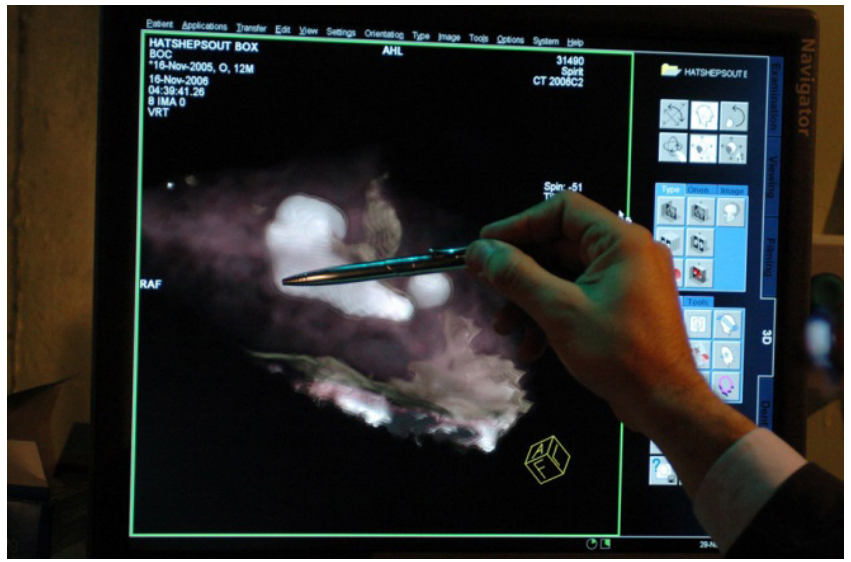

Figure 2: A rootless molar was found in the chest containing Hatshepsut's liver which was scanned, $\odot$ The Supreme Council of Antiquities

\section{Acknowledgement}

Many thanks to Dr Zahi Hawass, whose help was most valuable to me.

\section{References}

1. Maruéjol Florence (2007) Thutmose III and Hatshepsut: a throne for two regents. Historia n 729: 24-9.

2. Battaggion $V(2007)$ The mummy who did not have all her teeth. Historia $n^{\circ} 729: 30-1$.

3. Hawass $Z$ (2007) The search for Hatshepsut and the discovery of her mummy. 1-7.

4. Hawass Z (2007) Identifying Hatshepsut's mummy. 1-9.

5. Riaud X (2008) Quand la dent mène l'enquête..., [When teeth lead the investigation] L'Harmattan (ed.), Collection Médecine à travers les siècles Paris.

6. The Supreme Council of Antiquities, Egyptian Mummy Project, Dr Zahi Hawass, director, Cairo, Egypt, 2008.

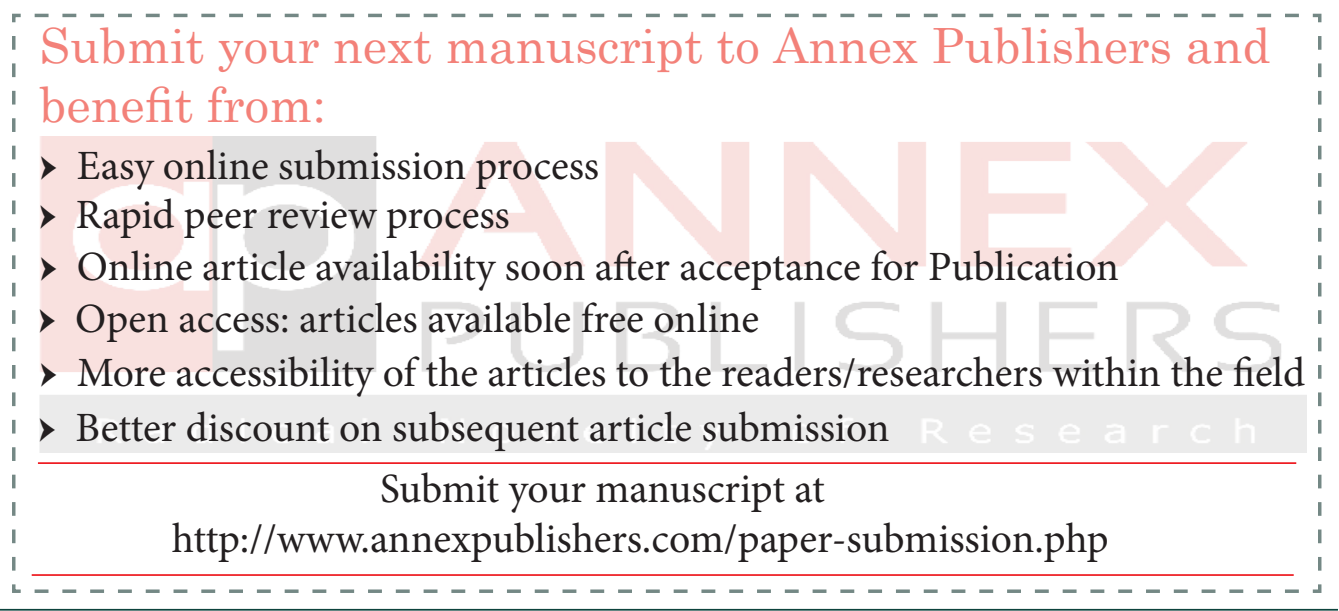

